\title{
The Effect of Teachers' Written Corrective Feedback (WCF) Types on Intermediate EFL Learners' Writing Performance
}

\author{
Khadijeh Aghajanloo (Corresponding author) \\ University of Zanjan, Iran \\ E-mail: khadijeh.aghajanloo@gmail.com \\ Fariba Mobini \\ University of Zanjan, Iran \\ Robab Khosravi \\ University of Zanjan, Iran
}

Doi:10.7575/aiac.alls.v.7n.3p.28

Received: 14/01/2016

URL: http://dx.doi.org/10.7575/aiac.alls.v.7n.3p.28

Accepted: 24/02/2016

\begin{abstract}
Written Corrective Feedback (WCF) is a controversial topic among theorists and researchers in L2 studies. Ellis, Sheen, Murakami, and Takashima (2008) identify two dominant dichotomies in this regard, that is focused vs. unfocused WCF and direct vs. indirect WCF. This study considered both dichotomies in a matrix format, resulted in the recognition of four types of operationally defined WCF, and aimed at: (1) investigating the effects of four types of WCF (i.e., focused direct $\mathrm{CF}$, unfocused direct $\mathrm{CF}$, focused indirect $\mathrm{CF}$, and unfocused indirect $\mathrm{CF}$ ) on intermediate EFL learners' writing performance; (2) finding out the most effective type of WCF for intermediate EFL learners' writing performance; (3) determining learners' attitudes toward the effectiveness of using WCF and the types which they had received. After conducting Nelson English Language Test (Test 300 D), out of 140 male and female Iranian EFL learners, 120 of them were selected as intermediate learners, aging from 14-18. The subjects were then assigned randomly to four homogeneous groups (each group including 30 participants). The pre-test and post-test both included a writing test which assessed learners' writing performance, and then their scores were analyzed by using analytic marking scale. The results indicated that, learners outperformed in all of the four groups, validating WCF as an effective technique which can be used in EFL classes. A clear implication of the study is that WCF types (specially unfocused direct CF) should be emphasized as an essential tool for developing writing ability of intermediate EFL learners.
\end{abstract}

Keywords: Written Corrective Feedback (WCF), Focused CF, Unfocused CF, Direct CF, Indirect CF, Writing Performance, Intermediate EFL Learners

\section{Introduction}

Writing is usually thought to be the most complicated skill for foreign language learners to acquire and can only be taught after introductory acquaintance with elements of language (Sadeghi \& Mosalli, 2013). Learning writing entails basic familiarity with higher level sub skills of planning and organizing, as well as lower level sub skills of spelling, word choice, and mechanics of writing (Richards, 2002). Writing is an outlet for emotions and thoughts, and despite the fact that writing skill come late on the process of acquisition, it still forms an important component of second/foreign language learning (Fageeh, 2011, cited in Hosseini, Naseri, Taghizade \& Zeinol Abedin, 2013). Many attempts have been geared toward helping EFL learners improve their writing skill. One such attempt is providing written corrective feedback, and in the recent years many studies have been conducted to investigate the nature of feedback and the role it might play in L2 teaching and learning (Lyster \& Ranta, 1997).

Ellis (2009) suggests various strategies for providing feedback, and analyzes student responses to the various types of feedback by focusing on linguistic errors. Guenette (2007) states that teachers need to investigate various types of feedback and their effect on student writing and error correction. Ellis, Sheen, Murakami, and Takashima (2008) identify two dominant dichotomies in this regard, that is focused vs. unfocused WCF as well as direct vs. indirect WCF. This study considered both dichotomies in a matrix format resulted in the recognition of four types of operationally defined WCF, and tended to investigate the comparative effectiveness of these techniques on promoting EFL learners` writing performance.

The main purpose of this study was to investigate the effects of four types of Written Corrective Feedback (i.e. focused direct $\mathrm{CF}$, unfocused direct $\mathrm{CF}$, focused indirect $\mathrm{CF}$, and unfocused indirect $\mathrm{CF}$ ) on intermediate EFL learners' writing performance, and to find which type of written corrective feedback might result in better gains. Moreover, the other aim of this study was to determine participants' attitudes regarding the techniques they had received. 


\section{Literature Review}

\subsection{Writing Performance}

According to Richards and Schmidt (2010), performance is defined as “a person's actual use of language. A difference is made between a person's knowledge of a language (competence) and how a person uses this knowledge in producing and understanding sentences (performance). There is also a somewhat different way of using the term performance. In using language, people often make errors (such as speech errors). The errors they make are described as examples of performance" (p. 428). Writing performance has three main sub sections (i.e., accuracy, fluency, and complexity). Many researches have been conducted within the framework of writing performance, focusing in particular on studies involving the effects of different strategies (such as task complexity, task types, and task condition) on accuracy, fluency and complexity of L2 written performance.

\subsection{Written Corrective Feedback (WCF)}

Richards and Schmidt (2010) define feedback as "comments or other information that learners receive concerning their success on learning tasks or tests, either from the teacher or other persons" (p. 217). Written corrective feedback is defined as teacher's input to a writer's composition in the form of information to be used for revision (Keh, 1990). It is also defined as information provided by teachers to help students trouble-shoot their performance (Nicole and Macfarlane, 2006). Corrective feedback has been a concern of various researchers for centuries (e.g., Brookhart, 2008; Ferris \& Hedgcock, 2004; Hyland, 2010; Kroll, 2003; Leki, 1991; Reid, 1998).

There is a rapid growth of interest in different areas of research into feedback on writing and the continuing search by teachers for ways to make their feedback practices more effective. In the last two decades feedback has become a central issue for writing research. "Recently much feedback research has centered on strengthening the links between feedback on writing and SLA theories and has sought to investigate whether feedback has an effect on language proficiency and development, with a focus on the potential role of written corrective feedback (WCF)" (Hyland, 2010, p. 172).

Corrective Feedback (CF) in L2 writing research is a controversial issue and an important factor in learning. Feedback is defined as information provided by teachers to help students trouble-shoot their performance (Nicole and Macfarlane, 2006). CF on L2 learners' writing can take many different forms. According to Ellis, Sheen, Murakami, and Takashima (2008), there are two main categories of written corrective feedback; that is focused vs. unfocused CF and direct vs. indirect $\mathrm{CF}$.

\subsubsection{Focused vs. unfocused CF}

As Van Beuningen (2010) states "the focused-unfocused dichotomy refers to the comprehensiveness of correction methodologies. The unfocused (or comprehensive) approach involves correction of all errors in a learner's text, irrespective of their error category. Focused (or selective) CF, on the other hand, targets a number of specific linguistic feature(s) only (e.g. errors in the use of English articles). Errors outside the focus domain are left uncorrected"(p. 11).

Different predictions have been made with respect to the relative effectiveness of focused and unfocused CF. Ellis et al. (2008) claimed that there are theoretical reasons for expecting the focused approach to be more beneficial to accuracy development than unfocused CF. They stated that learners are more likely to notice and understand corrections when they target a specific set of error types. The idea that noticing and understanding are essential for acquisition (e.g. Ellis, 2005; Schmidt, 1994), led Ellis et al.(2008) to conclude that focused CF has greater potential to impact accuracy development.

Sheen (2007) and Bitchener (2008) argued that unfocused CF may not be the most effective correction method because L2 learners have a limited processing capacity. They claimed that asking learners to deal with CF which targets a broad range of linguistic features at the same time might produce a cognitive overload, and prohibit feedback processing.

There are also reasons to question the hypothesized superiority of a focused CF approach. It could be argued that focused $\mathrm{CF}$ is a form of explicit grammar instruction than a focus-on-form intervention (e.g., Bruton, 2009). This might make it more difficult for learners to transfer what is learned from the feedback to new writing situations. Furthermore, Ferris and Storch (2010) noted that, from a practical perspective, only targeting specific error types might not be enough; a teacher's purpose in correcting his pupils' written work is improving accuracy in general, not just the use of one grammatical feature. Moreover, observing that some of their errors have been corrected while others have not might be confusing for students.

\subsubsection{Direct vs. indirect CF}

The main factor distinguishing between direct and indirect CF is the learner's participation in the correction process. "Whereas direct CF consists of an indication of the error and the corresponding correct linguistic form (Lalande, 1982; Robb et al., 1986; Semke, 1984; Van Beuningen et al, 2008; 2012), indirect CF only indicates that an error has been made" (Van Beuningen, 2010, p.12). Indirect corrective feedback is when the teacher underlines, circles or highlights errors on students' original texts, indicating the location of these errors without correcting them, students are asked to study their errors and correct them (Bitchener \& Knoch, 2010b; Van Beuningen, 2008).

"Various hypotheses considering the effectiveness of direct and indirect CF have been put forward, some in favor of direct error correction, others supporting the indirect approach" (Van Beuningen, 2010, p. 12). 
On the one hand, it has been suggested that learners will benefit more from indirect CF because they have to engage in a more profound form of language processing when they are self-editing their writing (e.g., Ferris, 1995; Lalande, 1982).In this view, the value of the indirect approach lies in the fact that "it requires pupils to engage in guided learning and problem solving and, as a result, promotes the type of reflection that is more likely to foster long-term acquisition" (Bitchener \& Knoch, 2008, p. 415).

Advocates of direct CF (e.g., Chandler, 2003), on the other hand, have claimed that the indirect approach might fail because indirect $\mathrm{CF}$ provides learners with insufficient information to resolve complex errors (e.g., syntactic errors). Chandler (2003) argued that, while direct CF enables learners to instantly internalize the correct form as provided by their teacher, learners whose errors are corrected indirectly do not know if their own hypothesized corrections are indeed accurate. This delay in access to the target form might level out the potential advantage of the additional cognitive effort associated with indirect CF. Additionally, Bitchener and Knoch (2010) suggested that only direct CF offers learners the kind of explicit information that is needed for testing hypotheses about the target language.

It has also been suggested that the relative effectiveness of direct and indirect CF methodologies might be determined by intervening factors, such as a learner's level of L2 proficiency or meta-linguistic awareness (e.g., Ferris, 2004; Hyland \& Hyland, 2006), the type of error that is targeted (e.g., Ferris, 1999; 2002), the goal a teacher tries to achieve by providing CF (Ferris, 2010), or the type of knowledge (i.e., already partially acquired knowledge vs. new knowledge) a teacher wants to transfer (Ellis et al., 2008).

Considering all these controversies and taking into account the importance of feedback studies, the present study attempts to investigate the effects of providing four types of written corrective feedback (WCF) on EFL learners' writing performance.

\subsection{The Present Study}

One of the aims of this study was to investigate the effects of four types of WCF (i.e., focused direct CF, unfocused direct $\mathrm{CF}$, focused indirect $\mathrm{CF}$, and unfocused indirect $\mathrm{CF}$ ) on intermediate EFL learners' writing performance. Also, the other aim of this study was to find which type of written corrective feedback might result in better gains and seeking learners' attitudes regarding the effectiveness of using WCF and the types which they had received. In this study the following questions are addressed:

1. Is there any significant difference across the four types of WCF (i.e. focused direct $\mathrm{CF}$, unfocused direct $\mathrm{CF}$, focused indirect $\mathrm{CF}$, and unfocused indirect $\mathrm{CF}$ ) as far as the results are concerned?

2. Which type of WCF has been the most effective technique?

3. Do learners have different attitudes regarding the effectiveness of using WCF and the types which they have received?

\section{Method}

\subsection{Participants}

The participants of this study were 140 male and female intermediate EFL learners studying English (i.e., Top Notch 3A) at private language institutes in Iran. In order to ensure that subjects were at the same proficiency level, Nelson English Language Test (Test 300 D) was administered prior to the treatment. Out of 140 participants who took the test, 120 (i.e., 51 male, 69 female) of them whose scores were above 30 were selected to serve as the subjects of the study and learners with other levels of proficiency were disregarded from the study without being aware themselves. Ages ranged from fourteens to eighteens, but the majority was fifteen years old and the average age of the participants was 16.7. The subjects were then assigned randomly to four homogeneous groups (each group including 30 participants).

\subsection{Instruments}

\subsubsection{Nelson Proficiency Test}

Nelson English Language Test (i.e., Test 300 D) was used to homogenize the proficiency level of learners and to ensure the homogeneity of the participants in four groups in terms of their English language knowledge. Nelson English Language Test is "a battery of tests consisting of separate items for ten levels of language proficiency. Each test consists of 50 items. The tests are designed for a 30 (60\%) pass- mark" (Khazaei, 2011, p.203).

\subsubsection{Writing Tests}

A pre-test in writing was administered to reveal the participants' level of writing prior to the treatment. At the end of the term (i.e., 18 subsequent sessions), each subject was given a post-test similar to the pre-test to find out whether the treatments had any significant effect on the improvement of learners' writing performance. The topics of the pre-test and post-test were selected from TOEFL writing topics. These topics were similar in format, instruction, length, level of difficulty, and allotted time. In order to score these tests, the analytic marking scale was used.

Due to the nature of the pilot study which is to find out any probable ambiguities or problems of the research, a pilot study was conducted in order to estimate how long it would take to administer the writing tests and also to assess the feasibility of each test; that is, weather their instructions and statements were clear enough for Iranian intermediate EFL learners. The pilot study's sample comprised a small group of subjects with characteristics similar to the subjects in the main study. The sample consisted of 20 subject including11 girls and 9 boys from two classes. 
It should have taken about 40 minutes for subjects to complete the proficiency test, and 30 minutes to finish each writing test (i.e., pre- and post-test); however most of the subjects spent about 120 minutes on taking the tests (i.e., the proficiency test and the writing tests). As for the feasibility of the tests, most participants were able to understand the topics of the writing well, which revealed that the instructions were explicit and comprehensive for the subjects.

All of the learners' writings (i.e., pre- and post-test) were scored by two raters for assessing inter-rater reliability. In order to estimate inter-rater reliability, Pearson product-moment correlation coefficient was used. In this study, the calculated $r$ was .81 which indicated that there was a large positive correlation between two raters.

\subsubsection{Attitude Questionnaire}

A questionnaire, seeking learners' attitudes concerning the effectiveness of using WCF and the types which they had received during the treatment, was adapted from Mubarak (2013) in order to illuminate learners' possible differential attitudes toward WCF types. It had fifteen items and it was based on Five Point Likert Scale, which provided five responses to each statement. This questionnaire was divided into four subcategories which were General Attitude to Feedback ( 3 items), Preference of and Attitude to Feedback Type ( 4 items), Post-Feedback Behavior (5 items), and SelfRating of Improvement (3 items). Learners' responses to the items were statistically analyzed and subsequently compared to provide a comprehensive picture of their attitudes toward WCF types.

There was a pilot study in order to illuminate the validity and reliability of the questionnaire. Therefore, it was piloted first by five TEFL experts, and then administered to 20 subjects with similar background and level of English proficiency. After these procedures, some of the items were rephrased and the order of some statements was altered. The reliability of the piloted questionnaire was calculated by Cronbach's alpha. Pallant (2001) states that, "the Cronbach alpha coefficient of a scale should be above 0.7 " (p.85). The result of calculation was $a=.72$ which confirmed that the questionnaire was reliable and could be used for collecting the data about learners' attitudes toward WCF types.

\subsection{Data Collection Procedure}

In order to complete this study, three stages were followed:

Stage One:

In order to select a homogenized sample in terms of language proficiency, 140 EFL learners from fourteen classes of 'Top Notch 3A' from different English Language institutes (i.e., four institutes) in Iran were administered a proficiency test. As mentioned earlier, Nelson English Language Test (Test 300 D) consists of 50 multiple-choice items. Results of this test provided each of the participants with a score out of 50 which allowed the researcher to see exactly how they performed. Out of the 140 participants who took the test, 120 of them whose scores were above 30 were selected to serve as the subjects of the study and learners with other levels of proficiency were disregarded from the study without being aware themselves. The subjects were then assigned randomly to four homogeneous groups (each group including 30 participants).

Stage Two:

A pre-test in writing was administered to reveal the participants' level of writing prior to the treatment. The topic of this writing was selected from TOEFL writing topics. As mentioned earlier, there was a pilot study before giving the topic to participants in order to estimate how long it would take to administer the tests and also to assess the feasibility of each test; that is, weather their instructions and statements were clear enough for Iranian EFL learners. The measure which was employed to evaluate and score participants' writings was analytic marking scale. This analytic marking scale with specific paragraph evaluation criteria was adopted from Jacobs et al's (1981), (cited in Testing for Language Teachers by Hughes, 2003). It consists of six components: content, organization, vocabulary, cohesion, grammar, and form. Each component was analyzed and graded by its respective five-degree scale (from 1 as minimum to 5 as maximum), so that the total score of each test ranges from 1 as the minimum to 30 as the maximum.

Subjects in four experimental groups were asked to write different paragraphs (i.e., five writings) corresponding to the units that they had already covered in the class during the term. The topics of all the writing assignments were the same for all the four groups and determined by each unit of the book. These writings were corrected based on the type of the treatments they had received, i.e., focused direct CF, unfocused direct CF, focused indirect CF, and unfocused indirect CF.

\section{Stage Three:}

At the end of the term (i.e., 18 subsequent sessions), each subject was given a post-test similar to the pre-test to find out whether the treatments had any significant effect on the improvement of learners' writing performance. The topic of the post-test was also selected from TOEFL writing topics and as stated above there was a pilot study for the post-test topic. These topics were similar in format, instruction, length, level of difficulty, and allotted time. Once again to score the post-test, the analytic marking scale was used.

An attitude questionnaire was attached to the post-test in order to seek learners' attitudes concerning the effectiveness of using WCF and the types which they had received during the treatment. This questionnaire had fifteen items and it was based on Five Point Likert Scale and the responses were statistically analyzed to provide a comprehensive picture of learners' attitudes toward WCF types. 
3.4 Data Analysis

SPSS version 16 was used to analyze the collected data. The scores obtained from participants' writing pre- and posttest were compared to reveal if there were any significant differences in writing performance of four experimental groups, and to determine which type of WCF resulted in better gains. Differences between the mean scores of the preand post-test of each four groups were calculated through paired t-test. The scores of pre- and post-test of the four groups were compared by one-way ANOVA to find out whether the treatments had any significant effect on learners' writing performance.

The differences between the gains of the four experimental groups were compared by multiple comparisons to find out which type of WCF might be more efficient for intermediate EFL learners. Finally, learners' responses to attitude test were collected and statistically analyzed to illuminate learners' attitudes concerning the effectiveness of WCF and the types which they had received during the treatment. All of these statistical analyses were used to test this study's three hypotheses:

$\mathrm{H}_{01}$ : There is no significant difference across the four techniques concerning their effect on the learners' writing performance.

$\mathrm{H}_{02}$ : Focused direct CF contributes more to learners' writing development.

$\mathrm{H}_{03}$ : There is no significant difference across learners' attitudes regarding WCF types.

\section{Results}

About 140 EFL learners from fourteen classes of 'Top Notch 3A' were administered a proficiency test. The range of the learners in these fourteen classes was different, from 5 learners in some classes up to 16 learners in other classes. Out of the 140 participants who took the test, 120 of them whose scores were above 30 were selected to serve as the subjects of the study and learners with other levels of proficiency were disregarded from the study without being aware themselves.

Table 1. Descriptive statistics: Nelson proficiency test (300D)

\begin{tabular}{|c|c|c|c|c|c|c|}
\hline & $\mathrm{N}$ & Mean & $\begin{array}{c}\text { Std. } \\
\text { Deviation }\end{array}$ & Std. Error & Min & $\operatorname{Max}$ \\
\hline Group 1 & 30 & 34.23 & 1.99 & 0.36 & 31 & 37 \\
\hline Group 2 & 30 & 34.87 & 1.85 & 0.34 & 32 & 38 \\
\hline Group 3 & 30 & 34.93 & 1.53 & 0.28 & 32 & 37 \\
\hline Group 4 & 30 & 34.10 & 2.04 & 0.37 & 31 & 38 \\
\hline
\end{tabular}

Table 1 presents the results of Nelson Proficiency test with regard to the selected groups. Group 1 (i.e., focused direct CF) had thirty subjects and their mean score was 34.23 out of 50. Similarly, Group 2 (i.e., unfocused direct CF) had thirty subjects and their mean score was 34.86 out of 50. Group 3 (i.e., focused indirect CF) had thirty subjects and their mean score was 34.93 out of 50. And finally, Group 4 (i.e., unfocused indirect CF) had thirty subjects and their mean score was 34.1 out of 50 .

Table 2. Descriptive statistics: One-way ANOVA in the Nelson proficiency test (300D)

\begin{tabular}{llcccc}
\hline & SS & DF & MS & F & p \\
\hline Between & 16.466 & 3 & 5.488 & 1.58 & 0.197 \\
Within & 403.4 & 116 & 3.477 & & \\
Total & 419.866 & 119 & & & \\
\hline
\end{tabular}

Table 2 presents the results of one-way ANOVA which was run between the mean scores of the four groups. With an alpha level decided at $\mathrm{p}<.05$ level of significance, there were not any significant differences between the four groups, which along with the randomization showed that the four groups were homogeneous. 
4.1 Investigation of Research Question 1

Regarding the first research question (Is there any significant difference across the four types of WCF (i.e., focused direct $\mathrm{CF}$, unfocused direct $\mathrm{CF}$, focused indirect $\mathrm{CF}$, and unfocused indirect $\mathrm{CF}$ ) as far as the results are concerned?), an attempt was made to make a comparison between the results obtained from the pre- test and the post-test of four groups to see whether there are any significant differences in their writing performance. Furthermore, the mean scores of posttests in four groups were compared to reveal that if there were any significant differences in their writing performance.

Table 3. Descriptive statistics: One-way ANOVA in the post-test

\begin{tabular}{lccccc}
\hline & SS & DF & MS & F & $p$ \\
\hline Between & 104.5 & 3 & 34.83 & 4.723 & 0.004 \\
within & 855.4 & 116 & 7.374 & & \\
Total & 959.9 & 119 & & & \\
\hline
\end{tabular}

As Table 3 shows, with an alpha level decided at $p<.05$ level of significance, the differences between groups were significant. Therefore, the subjects in the four groups differed in their performance in the post-test. Paired samples ttests were used to investigate any statistically significant differences in results in the pre-test compared with post-test for each four group. In this regard, Table 4 reports the results of paired sample t-test for four groups.

Table 4. Paired T-Test Result for four Groups (Differences between Pre-and Post-test)

\begin{tabular}{lllllll}
\hline & Test & $\mathrm{N}$ & Mean & $\begin{array}{l}\text { Std. } \\
\text { Deviation }\end{array}$ & T- value & $\begin{array}{c}\text { Sig.(2- } \\
\text { tailed) }\end{array}$ \\
\hline \multirow{2}{*}{ Group 1 } & Pre & 30 & 15.27 & 2.45 & 6.279 & 0.000 \\
& Post & 30 & 19.37 & 2.61 & & \\
Group 2 & Pre & 30 & 15.50 & 2.53 & 6.914 & 0.000 \\
& Post & 30 & 20.53 & 3.08 & & \\
& & & & & & \\
Group 3 & Pre & 30 & 15.17 & 2.45 & 4.209 & 0.000 \\
& Post & 30 & 17.90 & 2.58 & & \\
& & & & & & \\
Group 4 & Pre & 30 & 15.13 & 2.43 & 6.461 & 0.000 \\
& Post & 30 & 19.30 & 2.56 & & \\
\hline
\end{tabular}

Tables 4 shows that the writing performance of the learners in all four groups improved significantly, but the second group (i.e., unfocused direct $\mathrm{CF}$ ), the fourth group (i.e., unfocused indirect $\mathrm{CF}$ ), and the first group (i.e., focused direct $\mathrm{CF}$ ) respectively performed better than the third group (i.e., focused indirect $\mathrm{CF}$ ). Therefore, the results show that there were significant differences between the four performances in favor of the post scores at the level of $\mathrm{P}<.05$. So the first null hypothesis that (There is no significant difference across the four techniques concerning their effect on learners' writing performance.) was rejected.

\subsection{Investigation of Research Question 2}

Regarding the second research question (Which type of WCF has been the most effective technique?), based on the statistical analysis, and also with a close look at Figure1, it can be claimed that unfocused direct corrective feedback (i.e., providing the correct form for all linguistic errors by crossing out the errors and writing the correct forms above them) was the most effective technique (among the other three types) for intermediate EFL learners' writing performance. Therefore the second null hypothesis (Focused direct CF contributes more to learners' writing development.) was rejected. 


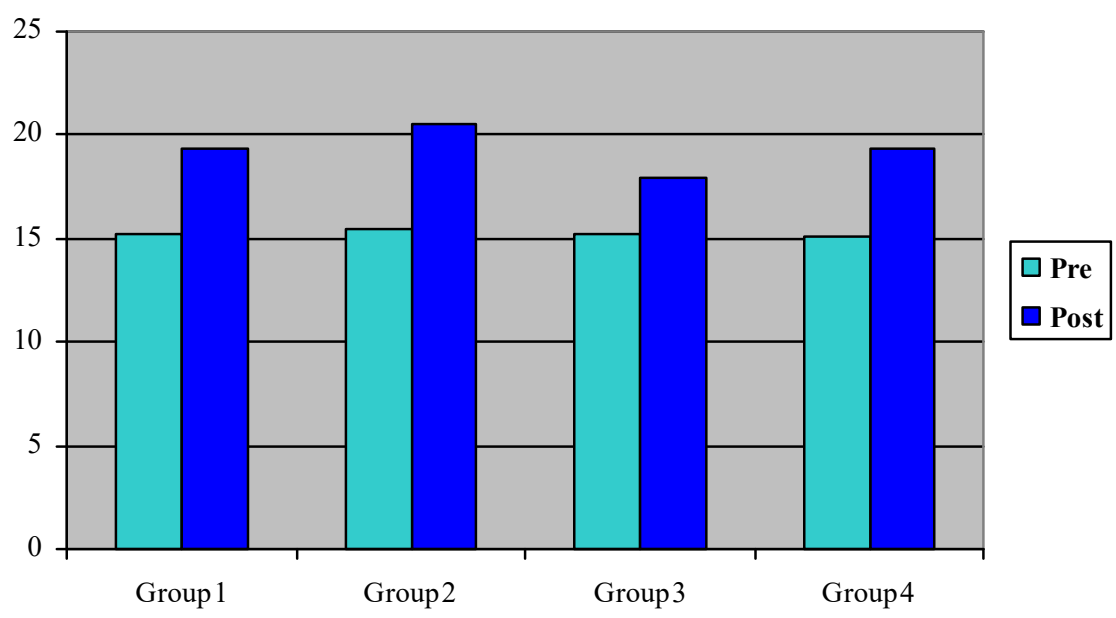

Figure 1. Differences of the Mean scores in the Pre-and Post-test

\subsection{Investigation of Research Question 3}

Regarding the third research question (Do learners have different attitudes regarding the effectiveness of using WCF and the types which they have received?); Figure 2 illustrates learners' preference of and attitude concerning the WCF types which they had received.

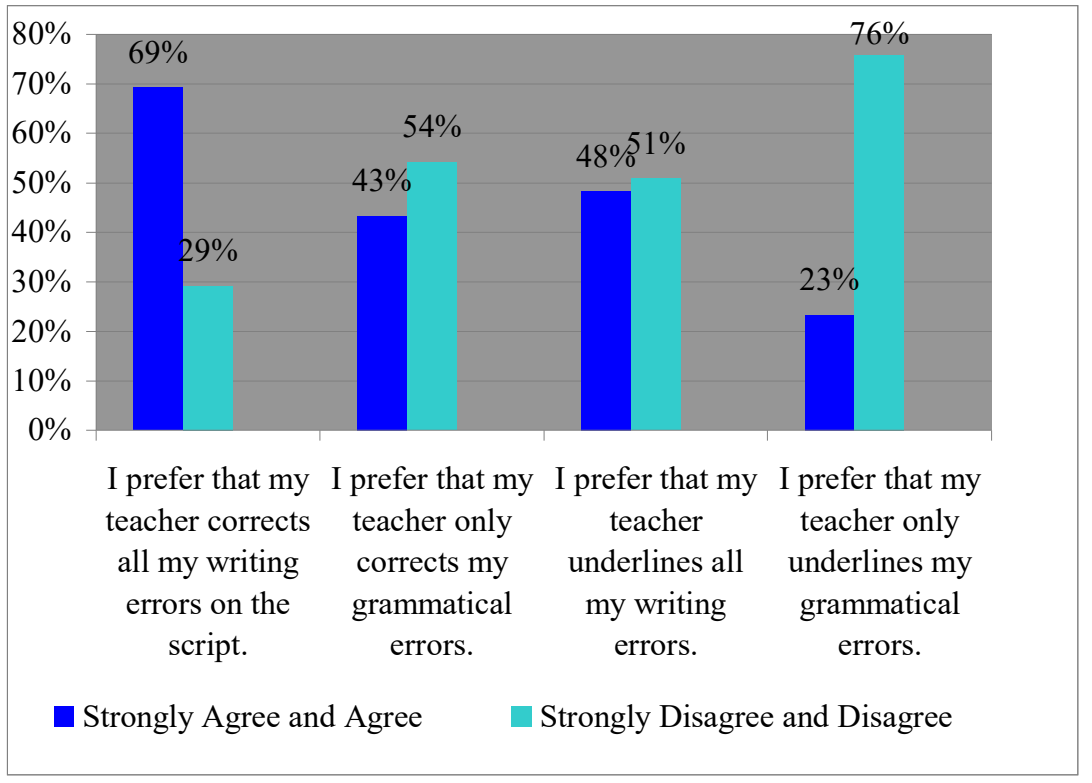

Figure 2. Learners' Preference of and Attitude to Feedback Type (4-7)

Figure2 reveals that the majority of learners (69\%) prefer unfocused direct corrective feedback as the most useful technique (i.e., they prefer their teachers correct all their writing errors on the script). Interestingly, $76 \%$ of the learners disagree with focused indirect corrective feedback (i.e., they don't prefer their teachers only indicate the grammatical errors by underlining them without any correction). Therefore, the third null hypothesis (There is no significant difference across learners' attitudes regarding WCF types.) was rejected.

\section{Discussion and Conclusion}

\subsection{Addressing the First Research Question}

The result of the first question revealed that there were significant differences between the mean scores of the four groups in writing performance (i.e., all of the four groups performed better in the post-test compared to the pre-test). Hence, results showed that all of the four types of written corrective feedback (i.e., focused direct CF, unfocused direct $\mathrm{CF}$, focused indirect $\mathrm{CF}$, and unfocused indirect $\mathrm{CF}$ ) can positively affect intermediate EFL learners' writing performance.

The findings of this study are in line with previous researches suggesting written corrective feedback is an effective technique for enhancing EFL learners writing performance (e.g., Bitchener, 2008; Bitchener \& Knoch, 2009; Chandler, 2004, 2009; Ellis et al., 2008; Ferris, 1999 , 2004, 2006, 2010; Van Beuningen, 2010). 
With respect to the second research question (Which type of WCF has been the most effective technique?), results of the statistical analysis indicated that, unfocused direct corrective feedback (i.e., providing the correct form for all linguistic errors by crossing out the errors and writing the correct forms above them) is the most effective technique (among the other three techniques) for intermediate EFL learners' writing performance.

As stated earlier, different researchers had different ideas regarding the effectiveness of different types of WCF (i.e., focused vs. unfocused, and direct vs. indirect). Different predictions have been made about the effectiveness of focused and unfocused CF. Some of the researchers (e.g., Bitchener, 2008; Ellis, 2005; Ellis et al., 2008; Schmidt, 1994; Sheen, 2007) claimed that there are theoretical reasons for expecting the focused approach to be more beneficial to accuracy development than unfocused CF. Furthermore, Van Beuningen (2010) reports that "eight recent studies (Bitchener, 2008; Bitchener \& Knoch, 2008; Bitchener \& Knoch, 2009; Bitchener \& Knoch, 2010a; Bitchener \& Knoch, 2010b; Ellis, Sheen, Murakami, \& Takashima, 2008; Sheen, 2007; Sheen, 2010b) all found robust positive effects of focused WCF, and that the reported accuracy gains proved to be very durable. Other researchers (e.g., Bruton, 2009; 2010; Ferris, 2010; Hartshorn \& Evans, 2012; Storch, 2010; Van Beuningen, 2010) have found that unfocused CF has greater potential to impact writing development. According to their claim, only targeting specific types of errors might not be enough; a teacher's purpose in correcting his pupils' written work is improving accuracy in general, not just the use of one grammatical feature" (p. 15).

With respect to the effectiveness of direct and indirect CF different hypotheses have been suggested, some in favor of direct $\mathrm{CF}$ and others supporting the indirect CF. On the one hand, advocates of indirect CF (e.g., Bitchener \& Knoch, 2008; Ferris, 1995; Lalande, 1982) have suggested that learners will benefit more from indirect CF because they have to engage in a more profound form of language processing when they are self-editing their writing ; and also indirect feedback may be more useful for learners at higher proficiency levels as they have relatively advanced linguistic knowledge. On the other hand, advocates of direct CF (e.g., Bitchener \& Knoch, 2010b; Chandler, 2003; Van Beuningen, 2010) have claimed that direct CF enables learners to instantly internalize the correct form as provided by their teacher; and only direct CF offers learners the kind of explicit information that is needed for testing hypotheses about the target language.

Hartshorn and Evans (2012) found that "direct unfocused (comprehensive) WCF coupled with insight from skill acquisition theory can be both practical and effective in improving accuracy" (p. 1). They found "positively influenced L2 writing accuracy for the mechanical, lexical, and some grammatical domains" (p. 1). In other words, they believe that "word order, word choice, and some grammatical aspects of student papers may benefit from the implementation of direct unfocused (comprehensive) WCF that is manageable, meaningful, timely, and constant" (Ducken, 2014, p. 33). Therefore, the findings of this study are in line with those who have advocated unfocused direct CF as an effective technique to improve intermediate EFL learners' writing performance.

\subsection{Addressing the Third Research Question}

The results obtained from the third research question regarding the learners' attitudes concerning the effectiveness of using WCF and the types which they had received during the treatment were informative. Based on the results of the questionnaire, learners highly appreciate teachers' feedback (72\%) and they would like to receive more feedback (95\%). Furthermore, learners' responses reflect that the majority of them $(69 \%)$ prefer unfocused direct corrective feedback as the most useful technique (i.e., they prefer their teachers correct all their writing errors on the script). Interestingly, $76 \%$ of the learners disagree with focused indirect corrective feedback (i.e., they don't prefer their teachers only indicate the grammatical errors by underlining them without any correction).

Hartshorn and Evans (2012) cite several studies (Ferris, 2006; Leki, 1991) that indicate "L2 learners express a clear preference for unfocused (comprehensive) over focused WCF” (p. 5). Kamberi (2013) investigated the significance of teacher feedback in EFL writing for tertiary level foreign language learners. His study showed that the majority of the students participating in the study prefer direct corrective feedback from all the feedback strategies that have been used in the study. Mubarak (2013) conducted a study in which the results of his questionnaire showed that EFL students preferred direct corrective to indirect corrective feedback. So, this study is in line with those who have found that EFL learners prefer unfocused (comprehensive) direct WCF.

5.4 Conclusion

This study aimed at investigating the effects of four WCF types (i.e., focused direct CF, unfocused direct CF, focused indirect $\mathrm{CF}$, and unfocused indirect $\mathrm{CF}$ ) on intermediate EFL learners' writing performance; and also to find out which type of WCF may result in better gains. Moreover, the other aim of this study was to determine learners' attitudes toward the effectiveness of using WCF and the types which they had received. The results discussed above extend our understanding of the effectiveness of WCF types on learners' writing performance. The study provided insights of the most effective WCF type in EFL classes, and also learners' preference of and attitudes toward the effectiveness of using WCF and the types which they had received as well as recommendations for integrating WCF techniques into class setting. Based on the findings and discussions, the conclusions in this study can be summarized as follows:

1. The comparison of the writing test scores (i.e., pre- and post-test scores) in the four groups showed that learners outperformed in all of the four groups (i.e., writing performance of the learners in all four groups improved significantly), validating WCF as an effective technique which can be used in EFL classes. 
2. Unfocused direct corrective feedback (i.e., providing the correct form for all linguistic errors by crossing out the errors and writing the correct forms above them) is the most effective technique (among the other three types) for teaching English writing where participants in the second group showed significant improvement in the post writing test.

3. Learners' responses to the attitude questionnaire revealed that they highly appreciate teachers' feedback and they would like to receive more feedback. About their preference of and attitude to feedback type, the majority of them (69\%) prefer unfocused direct corrective feedback as the most useful technique (i.e., they prefer their teachers correct all their writing errors on the script).

This study can be significant to EFL teachers and curriculum developers as it informs them about the type of WCF which may be more efficient for intermediate EFL learners, i.e., unfocused direct CF. Also, the results of this study can be significant for EFL teachers and learners as it represented an attempt to overcome the shortcomings of previous studies by investigating the effects of WCF on EFL learners' writing performance as a whole, not just focusing on one aspect of it. Repeating this study in other conditions would provide a better understanding of this issue. Teachers can investigate a variety of WCF strategies that might be appropriate in their own contexts.

\section{References}

Bitchener, J. (2008). Evidence in support of written corrective feedback. Journal of Second Language Writing, 17(2), 102-118

Bitchener, J., \& Knoch, U. (2008). The value of written corrective feedback for migrant and international students. Language Teaching Research Journal, 12(3), 409-431

Bitchener, J. and Knoch, U. (2009a). The relative effectiveness of different types of direct written corrective feedback. System, 37, 322-329.

Bitchener, J. and Knoch, U. (2009b). The value of a focused approach to written corrective feedback. ELT Journal, 63(3), 204-2011.

Bitchener, J. and Knoch, U. (2010b). Raising the linguistic accuracy level of advanced L2 writers with written corrective feedback. Journal of Second Language Writing, 19, 207-217.

Brookhart, S. M. (2008). Ho to give effective feedback to your students. Association for supervision and curriculum development.

Bruton, A. (2009). Designing research into the effect of error correction in L2 writing: not so straightforward. Journal of Second Language Writing, 18(2), 136-140

Chandler, J. (2003). The efficacy of various kinds of error feedback for improvement in the accuracy and fluency of L2 student writing. Journal of Second Language Writing, 12(3), 267-296

Ducken, D. (2014). Written Corrective Feedback in the L2 Writing Classroom. EUW Master's Thesis Collection. Paper 221.

Ellis, R. (2005). Principles of instructed language learning. System 33(2), 209-224.

Ellis, R. (2009). A typology of written corrective feedback types. ELT Journal, 63(2), 97-107.

Ellis, R., Sheen, Y., Morakami, M., and Takashima, H. (2008). The effect of focused and unfocused corrective feedback in an English as a foreign language context. System, 36, 353-371.

Ferris, D. R. (1995a). Can advanced ESL students be taught to correct their most serious and frequent errors? CATESOL Journal, 8, 41-62.

Ferris, D. R. (1995b). Student reactions to teacher response in multiple-draft composition classrooms. TESOL Quarterly, 29, 33-53.

Ferris, D. R. (1999). The case for grammar correction in L2 writing classes: a response to Truscott (1996). Journal of Second Language Writing, 8(1), 1-11.

Ferris, D. R. (2004). The "grammar correction" debate in L2 writing: Where are we, and where do we go from here? (And what do we do in the meantime?). Journal of Second Language Writing, 13(1), 49-62

Ferris, D. R. (2006). Does error feedback help student writers? New evidence on the short- and long-term effects of written error correction. In K. Hyland and F. 226 Hyland (Eds.), Feedback in second language writing: Contexts and issues (pp. 81-104). Cambridge: Cambridge University Press.

Ferris, D. R \& Hedgcock, J.S. (2004). Teaching ESL Composition. Purpose, Process, and Practice. Routledge. New York.

Guénette, D. (2007). Is feedback pedagogically correct? Research design issues in studies of feedback on writing. Journal of Second Language Writing, 16(1), 40-53

Hartshorn, K. J., \& Evans N. W. (2012). The differential of comprehensive corrective feedback on L2 writing accuracy. Journal of Linguistics and Language Teaching, 3(2), 25-50. 
Hosseini, M., Taghizadeh, M.E., Zainol Abedin, M. J., \& Naseri, E. (2013). In the importance of EFL learners' writing skill: Is there any relation between writing skill and content score of English essay test? International Letters of Social and Humanistic Sciences, 6, 1-12

Hughes, A. (2003). Testing for language teachers ( $2^{\text {nd }}$ ed). Cambridge: Cambridge University Press

Hyland, F. (2000). ESL writers and feedback: giving more autonomy to students. Language Teaching research, 4, 3354.

Hyland, F. (2010). Future directions in feedback on second language writing: Overview and research agenda. International Journal of English Studies, 1-12

Hyland, K., \& Hyland, F. (2006). Feedback on second language students' writing. Language Teaching Research Journal, 39(2), 83-101

Kamberi, L. (2013). The significance of teacher feedback in EFL writing for tertiary level foreign language learners. Procedia-Social and Behavioral Sciences, 70, 1686-1690

Keh, C. 1990. Feedback in the writing process: a model and methods for implementation. ELT Journal, 44, 94-304.

Khazaei, S. (2011). An Investigation into the Impact of Traditional vs. Blended Teaching on EFL Learners' Vocabulary Acquisition: M-learning in Focus. International Journal of Humanities and Social Science, 202-207

Kroll, B. (Ed.). (2003). Exploring the dynamics of second language writing. Cambridge: Cambridge University Press.

Lalande, J. F. (1982). Reducing composition errors: an experiment. Modern Language Journal, 66, 140-149.

Leki, I. (1991a). The preference of ESL students for error correction in college-level writing classes. Foreign Language Annuals, 24, 203-228.

Lyster, R. and Ranta, L. (1997). Corrective feedback and learner uptake: negotiation of form in communicative classrooms. Studies in Second Language Acquisition, 19(1), 37-66.

Mubarak, M. (2013). Corrective Feedback in L2 Writing: A Study of Practicies and Effectiveness in the Bahrain Context. Published Doctoral thesis. University of Sheffield.

Nicol, D. J., \& D. Macfarlane-Dick. (2006). Formative assessment and self-regulated learning: A model and seven principles of good feedback practice. Studies in Higher Education, 31(2), 199-218.

Pallant, J. (2001). SPSS Survival Manual. Buckingham: Open University Press.

Reid, J. (1998). Responding to ESL student language problems: Error analysis and revision plans. In P. Byrd \& J. Reid (Eds.), Grammar in the composition classroom (pp. 118-137). Boston: Heinle and Heinle.

Richards, J., \& Renandya, W. (2002). Methodology in language teaching. Cambridge: Cambridge University Press.

Richards, J. C. \& Schmidt, R. (2010). Longman Dictionary of Language Teaching and Applied Linguistics. (4th Ed). Pearson Education

Sadeghi, K. \& Mosalli, Z. (2013). The effect of task complexity on the quality of EFL learners' argumentative writing. Iranian Journal of Language Teaching Research, 1(2), 115-134

Schmidt, R. (1994). Deconstructing consciousness in search of useful definitions for applied linguistics. AILA Review $11,11-26$.

Sheen, Y. (2007). The effect of focused written corrective feedback and language aptitude on ESL learners' acquisition of articles. TESOL Quarterly, 41, 255-283

Sheen, Y. (2010a). The role of oral and written corrective feedback in SLA. Studies in Second Language Acquisition $32(2), 169-179$.

Sheen, Y. (2010b). Differential effects of oral and written corrective feedback in the ESL classroom. Studies in Second Language Acquisition, 32(2), 201-234.

Van Beuningen, C. (2010). Corrective Feedback in L2 Writing: Theoretical Perspectives, Empirical Insights, and Future Directions. International Journal of English Studies, 18(2), 1-27

Van Beuningen, C., de Jong, N. H., and Kuiken, F. (2008). The effect of direct and indirect corrective feedback on L2 learners' written accuracy. ITL International Journal of Applied Linguistics, 156, 279-296.

Van Beuningen, C., de Jong, N. H., and Kuiken, F. (2012). Evidence on the effectiveness of comprehensive error correction in Dutch multilingual classrooms. Language Learning, 61, 1-41. 